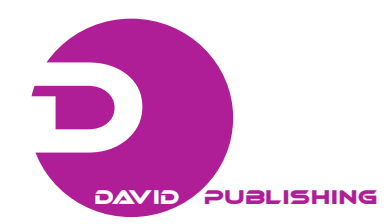

\title{
Ideology and Poetics in the Estonian Translations of Nikolai Leskov
}

\author{
Ljubov Kisseljovaa, Lea Pilda
}

\begin{abstract}
This paper brings up the issue of a systemic study of the translation of Russian classics into Estonian during the Soviet period. These translations are often considered to be only the result of the "Sovietization" of Estonian culture, but such approach is a simplification. Estonian translations of the Russian classics in the Soviet period, undoubtedly, depended on ideological conditions, but, it is argued here, were to a great extent determined by the mechanisms of cultural self-regulation and displayed continuity with translation strategies that had been established before the occupation, in the 1920s-1930s. In the independent Estonian Republic, a remarkable tradition of the translations of Russian classics existed thanks to the activity of A. H. Tammsaare, F. Tuglas, A. Oras, H. Talvik, B. Alver et al. Estonian translators devoted the particular attention to the text's audience-the Estonian readers. The paper explains why in the mid 1950s Leskov, an ambivalent and difficult-to-translate writer, was chosen by O. Samma and F. Kylli for the first presentation to the Estonian readers.
\end{abstract}

\section{Keywords}

Soviet cultural policy, two Soviet translation policy concepts, Estonian translation tradition, mechanisms of cultural self-regulation

It is well known that the dramatic increase of translations from Russian into Estonian [as it was to all national languages in the USSR (Union of Soviet Socialist Republics)] was a result of Soviet cultural policy and even strait governmental order. It was a demand to which local cultures had to obey. From 1940 to $1968,1,038$ literary texts were translated from Russian (including multi-tome collections of the works of Lev Tolstoy, Chekhov, Gorky, and Alexei Tolstoy), while 2,138 texts were translated into Estonian from other foreign languages, not including works from other Soviet republics (Nõukogude Eesti tõlkekirjandus 1970). It was a clear sign of state social order. But at the same time, it is worth to remind that happily a remarkable amount of Russian classics was translated in the period of the first Estonian Republic when this choice could be considered, so to say, "oppositional" to the mainstream of the governmental policy of the time. So, we would like to stress that in Estonia a well-established tradition of translations from Russian existed before the Soviet occupation. Estonia was home to exceptional translators who acknowledged the important place of "top tier" classic Russian authors among the brilliant masters of world literature. As early as 1939-1940, collected works of Dostoevsky in 15 volumes were published in Estonia (Dostoevsky 1939-1940); Chekhov's Selected Novellas, translated by Friedebert Tuglas, was published in 1939 (Chekhov 1939); and Pushkin's

aUniversity of Tartu, Tartu, Estonia

\section{Correspondent Author:}

Ljubov Kisseljova, Department of Slavic Studies, University of Tartu, Lossi 3, 51003, Tartu, Estonia 
Selected Poems (Puskin 1936) had been released three years earlier. Translators included Anton-Hansen Tammsaare, Ants Oras, Heiti Talvik, and other talented writers. Sadly, many excellent translators and critics emigrated during the WWII (Ants Oras, Gustav Suits, Marie Under, and Arthur Adson), others died in Stalin Gulag (Heiti Talvik). The others were forced to restrict themselves to translations because their original works could not be published at least for some decades (Betty Alver is the best example in this case). As it was in the Soviet Union on the whole, for "unwanted" writers, translation was the only possibility to earn a living. It would be a long list of great names to mention, let us limit ourselves with Anna Akhmatova and Boris Pasternak. But concentrating on Estonia, there was still a good amount of prominent translators who continued their work in the 1950s and 1960s alongside with their own creativity (Friedebert Tuglas, August Sang, Johannes Semper, et al.). Also, a new generation of translators was gaining strength.

So, although the increase in the number of translations was a clear manifestation of Soviet cultural policy, but it remained unknown to which extent each specific translation was a result of government regulations or, on contrary, a continuation of already existed cultural and translation traditions in Estonia. The Sovietization of Estonian culture, which began in 1940 after well-known political events, was a multidimensional and complex process not limited to the manifestation of ideological dictates (Torop 2002; 2011). Not all transformations in Estonian culture in the 1940s-1980s could be explained away by Sovietization; many were largely determined by mechanisms of cultural self-regulation ${ }^{1}$.

And still, in the new constrained circumstances, translators from Russian had to find a way among at least three conditions: (1) Soviet censorship, which included both the choice of the texts and authors, and the prescriptive conditions of translation theory and practice; (2) Estonian cultural tradition both in the sense of cultural priories in choice for translation and of the poetics and method of translation; and (3) the translators' own individual preferences.

\section{TWO SOVIET CONCEPTS OF TRANSLATION AND THE CHOICE OF LESKOV}

This paper will attempt to address these circumstances as they pertain to translations of the works of Nikolai Leskov (1831-1895) — a classic Russian author whose compositions are far from straightforward. This very ambivalent and tricky writer was really toughie task for translators. His style, based on skaz - that is, a creative take on the oral speech of common people (Eichenbaum 1969), is one of the most complex types of narrative in Russian literature.

Let us come closer to the first point. Firstly, we have to answer the question: Why was Leskov chosen? How could this writer who wrote on religious topics, developed the theme of the folk's faith, was not interested in the class struggle, and was strongly against the revolutionary movement satisfy the authorities of the Soviet cultural policy? We find the answer to this question in the article written by Maya Kucherskaya who had proved that Leskov's inclusion among the Russian classics happened in the Soviet Union during the WWII thanks to one of his novels which was interpreted as anti-German. So, Leskov was evolved from being viewed as a "reactionary" and "bourgeois" writer into an expert on Russian national life, who emphasized the positive aspects of the Russian national character (Kucherskaya 2014).

But still, there were much more "proper" Russian and Soviet writers to be translated in order to fulfill the Soviet demand and show the loyalty to the Soviet cultural policy. In this case, Leskov was definitely not the best choice.

And now, how did Leskov's style fit into the Soviet concept of translation which was strongly prescriptive, especially in the Stalinist period? Actually, we have to 
keep in mind that there were two concepts. The first one was meant for Soviet translators into Russian from foreign languages. They were forced to develop in a "smooth", "homogenized" style that excluded linguistic experimentation. Mikhail Gasparov wrote that, as a result of the demands for "simplicity", "understandability", "clarity", and "easiness" in a translated text, the translation took precedence over the original (Gasparov 1988). Translators who focused on the "precision" of a translation were subject to sharp criticism. They were accused of literalism, which had been considered a variation of formalism since the late 1940s (Azov 2013; Witt 2016a; Witt 2016b). Moreover, "realistic translation" declared the primary and exclusive method of Soviet translators, required a so-called "creative approach" to both the original text and its recreation (Kashkin 1953; Fedorov 1953).

The second concept was not declared loudly and concerned the translations from Russian into minority languages. As Maurice Friedberg and Susanna Witt had proved, in this case, "'literalism' was in fact encouraged” (Witt 2011: 156; Friedberg 1997: 184). In this context, Leskov's works which are full of linguistic experiments had to be translated into Estonian (as a minority language!) in the most exact literally way in order to show the virtues of Russian national character and even enrich the Estonian language by new words and constructions.

Leskov was practically unknown to Estonian readers up until 1955, when his first collection in translation was published, entitled The Enchanted Wanderer. Selection of Novels (Leskov 1955). In 1956, The Novellas (Leskov 1956) was published, and nine years later, in 1965, the collection The Life of a Peasant Woman. Selected Novels (Leskov 1965) was released. It appeared that the releases of these volumes were timed to coincide with the 60th and 70th anniversaries of Leskov's death. During this period, provincial and capital city publishing houses in Russia released numerous editions of Leskov's work-the most important of which were Collected Works in 11
Volumes (Leskov1956-1958).

As it was mentioned, Leskov's entrance into the Soviet canon was gradual and circuitous. The Soviet tendency toward a very biased reading of Leskov, which viewed him only as a denouncer of dark social powers and a sympathizer with the "oppressed class", inevitably influenced what works were selected for translation into Estonian. Thus, the translated stories The Wild Beast, The Darner, and The Toupee Artist became, in the Soviet context, examples of criticism of the exploiters, imperial society, etc. But, the works selected also reflected the new tendency to view Leskov as a spokesman for Russian national (peoples) life. This same time period saw the translation into Estonian of Nekrasov, Gleb Uspensky, and others considered experts on the Russian character. In complete accordance with the above-mentioned Soviet stance on the national character in Leskov's works, in editor V. Noorkõiv's introduction to a 1955 collection of Estonian translations, we find a list of the dominant ideas found in Leskov's prose, which boil down to a depiction of heroic characters who are "perfect", "brave", and "gifted". The poetics of the translations also bear signs of, on the one hand, the Soviet literary criticism of the 1940s-1950s, and on the other hand, an understanding of the goals of literary translation of the day. However, no one translated Leskov into Estonian in the 1950s-1960s "by accident"; all of his translations were completed by experienced masters who were well aware that his "linguistic excesses" make him difficult to translate.

But, turning to the second point of our reasoning, we will try to answer the question: Was there any intersection of the poetics of translation Leskov with the Estonian translation theory and practice from the previous independent times of the Estonian Republic?

\section{ESTONIAN TRANSLATION THEORY AND PRACTICE OF THE 1920S-1930S}

It comes out that the normative standards set by 
translation critics in Estonia in the first third of the twentieth century bear a typological (though not ideological!) similarity to Soviet standards for translations into Russian. As Estonian scholars demonstrated, beginning roughly in the second half of the 1900s, translation is described as a "creative activity" (Sütiste 2009) (a "recreation of the original", or even its "reshaping"), oriented, first and foremost, on the language of the translation and the translating culture (Torop 1999; Sütiste 2009). Undoubtedly, a profound difference is immediately noticeable: In the 1900s-1930s, Estonian culture mastered world classics; Estonian translators improved and enriched the stylistics of the Estonian language, attempting to adopt the "alien", but not adapting it straightforwardly to the "native"! Thus, neither the Estonian translation criticism of this period, nor the translations themselves, are ruled by a standard of simplification or homogenization of the language of the translation. Let us stress again: This is a crucial difference between a local tradition and prescriptive Soviet regulations.

And so, it is all the more important to follow the ways in which different translation standards clash and transform through the late nineteenth century example of Nikolai Leskov's difficult-to-translate prose. The very way in which Estonian translators in the 1950s approached Leskov's texts bears witness to their advanced level of preparation.

One of Leskov translators was Otto Samma (1912-1978), chairman of the translators section of the Union of Writers of the Estonian SSR (Soviet Socialist Republic), and the ideologue of translation in the 1950s-1960s in Estonia. As a translation theorist and a functionary at the same time, he wrote an article "On the Typical Shortcomings and Mistakes of Translations From Russian Into Estonian" (Samma 1954). In it, Samma summarizes the activities of Estonian translators of Russian classical and modern Soviet literature from 1940s through the mid-1950s. He touches upon many aspects of the theory and practice of literary translation and outlines the near future prospects for the work of Estonian translators. In the context of our case, let us stress that Samma is advancing an important thesis: The characteristics of a hero's speech are directly tied to the construction of his character. In certain cases, in Samma's opinion, the speech of a character reflects his internal evolution, his "spiritual growth". Notably, the author focuses on the very peculiarities of speech of "common folk" characters. Emphasizing on "sociolects" or "idiolects" which are so characteristic of Leskov, Samma is opening the pass to Leskov's translations into Estonian. Although the article conforms to the theoretical constructs of Russo-Soviet translation studies of the $1950 \mathrm{~s}^{2}$, at the same time, Samma delves into the problem of transmitting Russian "vernacular speech" in Estonian translation ${ }^{3}$.

The difficulty of transmitting vernacular speech was so significant that such speech was almost always diminished in Estonian translations of Tolstoy, Dostoevsky, or Chekhov in the pre-Soviet period. Translators occasionally found suitable equivalents for vernacular, colloquial, and dialectic words and phrases, intonations, and rhythms of oral speech, etc., and an inclusion of these words has been rare in the general background of the literary lexicon. One may say that typologically (though not functionally) such a translation is like a literary stylization - in particular, such stylization type in which the author depicts a past epoch without reproducing in detail the archaic speech of the characters, but at least occasionally including token words or turns of phrase that contrast with modern literary language. One example of such one-off tokens from Russian literature is the stylization of the modernist author Mikhail Kuzmin (Mints 2000). A parallel can also be drawn to the way in which nineteenth century Russian classic authors, such as Turgenev and Tolstoy, treated the speech of foreign characters speaking other languages: by beginning a dialogue or monologue in the foreign language, but thereafter continuing the speech in Russian. However, this structure of translated 
narration can be explained, in part, by the nature of Estonian creative writing. As the Estonian linguists Tiit Hennoste and Karl Pajusalu have elucidated (Hennoste and Pajusalu 2002: 120-123), beginning in the mid-1920s and continuing up through the beginning of the 1990s, creative texts were written in literary Estonian language; the use of dialect was strictly limited by compliance with regulatory requirements, and texts were subject to rigorous editorial revision. A few exceptions were made when the function of a dialogue was deemed to be a part of the characterization of a protagonist. Undoubtedly, this tendency was also reflected, to one degree or another, in translations.

In the Soviet times, the necessity of translating not only Leskov, but also, for example, Mikhail Zoschenko, presented Estonian translators with new challenges that seemed to be insurmountable by established means. However, it cannot be said that they found a distinctive approach to the translation of Leskov's skaz, which presupposes not only a grasp of the element of colloquial speech, but also a close cohesion between the voice of the narrator and the speech characteristics of the protagonists.

\section{TWO STRATEGIES OF TRANSMITTING LESKOV'S SKAZ}

And coming to the third point of our reasoning about the translators' own individual preferences, we have to point out that Samma's own translations from Leskov demonstrate deviations from his theoretical statements laid out in his prescriptive article of 1954. As a translator of Leskov, he avoids poeticisms and specific ("high") literary vocabulary when translating the speeches of commoner protagonists (the darner, the peasant, the cantor, the merchant, etc.). Journalese is absent from his translations as well. Rather than bother with a search for Estonian analogs to exotic vocabulary and phraseology, Samma uses neutral constructions or words in a conversational register as substitutes for historical realities, archaisms, dialectal expressions, and even grammar errors. Samma makes "common folk" characters speak in a version of Estonian that combines literary and conversational forms. In many ways, this style of translation is an extension of the prevailing local translation tradition. Maintaining Leskov's skaz form of narrative is not a goal for the translator, and vernacular speech is occasionally included for marking the socio-cultural or professional identity of a protagonist.

The other translator of Leskov into Estonian was Friedrich Kylli (1901-1978), a solidly experienced translator of Russian and Soviet literature ${ }^{4}$, and a writer, feuilletonist, and journalist, who himself used one of the southern Estonian dialects in his original compositions. The narration in his prosaic miniatures, or "humoresques", focuses on developing the narrator and modeling dialectic speech. Kylli is more distinctly considerate of Leskov's stylistic manner and attempts to find at least a partial solution to the translation of skaz.

In his translations of Leskov, Kylli, similar to Samma, most often neutralizes the Russian author's most skaz-like trait, the development of the voice of the narrator by eliminating diminutives, inversions, and occasionalisms, and filling in the gaps in elliptical constructions. But he devotes significantly more attention to the vernacular speech of characters in dialogues and monologues, employing a specialized translation strategy geared toward the text of the translation and the Estonian reader.

Kylli is also aware of the folkloric style of the novels The Life of a Peasant Woman and Lady Macbeth of the Mtsensk District, and of the fact that the behavior of Leskov's characters aligns with folklore plots in many ways. Although it is possible, we do not know whether Kylli has ever read Boris Eichenbaum's 1931 article about Leskov, which discusses Leskov's orientation toward popular (that is, folkloric) texts, but the translator well understands that the genre of lyrical song is important to both these 
novels. The words to the songs in The Life of a Peasant Woman Kylli translates himself, using Estonian folkloric formulas, and they organically blend into the stylistic texture of the translation. Vernacular speech is transmitted in translation mainly as speech with conversational connotations, based on established phrases, and the specific, occasional use of formulaic expressions from Estonian folk songs in the narrative. At times, he fairly accurately conveys the particular intonations of those characters which Leskov constructs with inversions, syntactic parallelisms, lexical repetitions, and frequent diminutives. Dialectisms and, particularly, archaisms are translated much less frequently. The translator's interest in the idiomatic aspect of speech manifests in a certain strengthening of that aspect (repeatedly, he uses idioms to translate phrases that are non-idiomatic in the original).

As we know from the history and theory of translation, making a translated text as accessible as possible to the readers is, as a rule, the first stage of acquainting him with the author from another culture. Leskov was first introduced to Estonian readers in the late 1950s and early 1960s. At that time, Kylli strove to create Estonian analogs to the vernacular and spoken Russian speech that characterized the skaz form of narrative used by Leskov. The translator treated Leskov's original texts very carefully, maintaining awareness of the specifics of his narration; nonetheless, we cannot say that Kylli's translations fully recreate the $s k a z$ style.

\section{CONCLUSIONS}

Summing up, it can be argued that Estonian translations of Russian classics in the Soviet period, undoubtedly, depended on ideological conditions. It was reflected in the selection of texts, in the introductions written to accompany translation collections, in the interpretation of the meaning and content of original works, and in a certain smoothness and simplicity of translation style. On the one hand, this last circumstance hindered the Russification of the Estonian language. It can be argued that this could be a way for Estonian translators to resist the Soviet regulations. On the other hand, orientation to the Estonian readers did not allow for the transmission of the uniquenesses of the original.

However, the strategies used by Estonian translators of the Russian classics and their implicit poetics in the Soviet era can be attributed to other influences: (1) existent of the pre-Soviet practices (including the translator's practice of transfer of the Russian classics and his own creative works); (2) translation norms formulated and tested in practice during the pre-Soviet period; (3) the unique evolution of Estonian literary language; and (4) the particular attention of the translator devoted to the text's audience - the Estonian readers.

\section{Acknowledgements}

The first version of this paper was presented at The First Annual Tartu Conference on Russian and East European Studies Europe Under Stress: The End of a Common Dream? June 12-14, 2016, Tartu, Estonia, at the panel Translation 4: Ideology, Tradition and the Market. The authors would like to express their gratitude to the panel organizer and chair Susanna Witt (Uppsala Centre for Russian and Eurasian Studies, Uppsala University, Sweden) and to all the panelists for a fruitful discussion.

\section{Funding}

This paper is written within the project IUT34-30 "Ideology of Translation and Translation of Ideology: Mechanisms of Cultural Dynamics Under the Russian Empire and Soviet Power in Estonia in the 19th-20th Centuries" funded by the Estonian Research Agency.

\section{Notes}

1. There is no basis for seeing all new translations only as an expression of Sovietization. In many ways, they simply continued the approaches to transmitting world literary works (Russian incl.) in Estonian already established in the 
1920s-1940s. When Johannes Semper translating in 1953 the poems of Pablo Neruda uses the original texts instead of using Russian as a linguistic intermediary, it is not just the only example of the continuation of previously existent translation practices in Estonia, as it is sometimes understood (A. Lange and D. Monticelli 2013: 892).

2. In accordance with these constructs, Samma works from the concept of "realistic translation" as opposed to a formalist or literal approach to the source text. He borrows terminology and metaphors from the works of contemporary Soviet translation scholars. Samma directly cites Vladimir Rossels' 1953 article "Translation and the National Peculiarities of the Original" published in the magazine Druzhba Narodov (Rossels 1955).

3. In a later article published in 1962, "A Little Something About Translation and Literature” (O. Samma 1962: 390), Samma does not appeal to Leskov's works, but clearly his search for equivalents in Estonian to the peculiarities of speech of an original text's characters is connected to translations of Leskov. These mannerisms are characterized as an important means of establishing a national character in a creative work. Furthermore, in his important article of 1962, Samma urges translators to demonstrate flexibility, starting from a particular author or text.

4. He translated, in particular, Tolstoy's "The Cossacks" and "Strider" and Gogol's "The Evenings in a Village Near Dikanka" (coauthored by Paul Viiding, 1952).

\section{References}

Azov, А. 2013. "Поверженные буквалисты" (Defeated Literalists). Из истории художественного перевода в CCCP в 1920-1960-егг. Москва (On the History of the Litarary Translation in the USSR in 1920s-1960s. Moscow).

Chekhov, A. 1939. Valik Novelle (Selected Novellas). Tõlk. Friedebert Tuglas (Translated by F. Tuglas). Tartu: Eesti Kirjanduse Selts.

Dostoevsky, F. 1939-1940. Kogutud teosed (Collected Works). Tartu; Tallinn: Loodus.

Eichenbaum, В. 1969. “Как сделана 'Шинель' Гоголя” (How Gogol's 'Overcoat' Was Made). Эйхенбаум Б. О прозе: Сб. статей (In B. Eichenbaum: On Prose. Selected Articles). Ленинград (Leningrad): Художественная литература. Рp. 306-326.

Fedorov, A. 1953. Введение в теорию перевода (Introduction Into the Theory of Translation). Москва (Moscow): Издательство литературы на иностранных языках.

Friedberg, M. 1997. Literary Translation in Russia. A Cultural History. University Park, PA: The Pennsylvania State UP.

Gasparov, M. 1988. "Брюсов и буквализм" (Bryusov and
Literalism). In Поэтика перевода (Poetisc of Translation). Москва (Moscow): Радуга. Рp. 29-62.

Hennoste, T. and K. Pajusalu. 2002. "Murded ja kirjakeel" (Dialects and Literary Language). In Eesti murded ja kohanimed. Toim. Tiit Hennoste (Estonian Dialects and Toponyms, edited by T. Hennoste). Tallinn: Eesti keele Sihtasutus. Pp. 116-123.

Kashkin, I. 1953. “Борьба за реалистический перевод” (The Struggle for a Realistic Translation). In Bonросы художественного перевода (Issues of the Literary Translation). Москва (Moscow): Советский писатель. Рр. 120-165.

Kucherskaya, M. 2014. Comrade Leskov: How a Russian Writer Was Integrated Into the Soviet National Myth. Retrieved (http://www.ruthenia.ru/National_myth/Kuchersk aya_Maya.pdf).

Lange, A. and D. Monticelli. 2013. "Tõlkelised ebakõlad totalitarismi monoloogis: Järjepidevused, katkestused ja varjatud konfliktid Nõukogude Eesti tõlkeloos" (Translational Inconsistencies in the Totalitarian Monologue: Continuity, Interrupts and Hidden Conflicts of the Soviet Estonian Translation History). In Keel ja Kirjandus (Language and Literature). No. 12. Pp. 881-898.

Leskov, N. 1955. Võlutud Rändur. Valik Jutustusi (The Enchanted Wanderer. Selection of Novels). Vene keelest tõlkinud L. Ojamaa (Translated from Russian by L. Ojamaa). Tallinn: Eesti Raamat.

—. 1956. Novellid (Novellas). Vene keelest tõlkinud O. Samma (Translated from Russian by O. Samma). Tallinn: Eesti Raamat.

—. 1965. Ühe naise elukäik: valimik jutustusi (The Life of a Peasant Woman: Selected Novels). Vene keelest tõlkinud Fr. Kõlli (Translated from Russian by F. Kylli). Tallinn: Eesti Raamat.

_. 1956-1958. Полное собрание сочинений в 11 томах (Collected Works in 11 Volumes). Москва (Moscow): Государственное издательство художественной литературы.

Mints, Z. 2000. 'К изучению периода 'кризиса символизма' (To the Study of the 'Crisis of Symbolism') (1907-1911). Вводные замечания (Introductory Marks).” Минц З.Г. Поэтика русского символизма (In Z. Mints. Poetics of Russian Symbolism). Санкт-Петербург (St. Petersburg): Искусство. Рp. 207-223.

Nõukogude Eesti tõlkekirjandus. 1940-1968. Bibliograafiline nimestik (Translated Literature in the Soviet Estonia. 1940-1968. Bibliography). 1970. Tallinn: Kirjastus "Eesti Raamat".

Pushkin, A. 1936. Valik Luulet (Selected Poems). Tartu: Eesti Kirjanduse Selts.

Rossels, V. 1955. "Перевод и национальное своеобразие 
подлинника" (Translation and the National Peculiarities of the Original). In Bопросы художественного перевода. Сборник Cтатей (Issues of the Literary Translation. Collection of Essays). Москва (Moscow): Советский писатель. Рр. 165-213.

Samma, O. 1954. "Tüüpilistest puudustest ja vigadest proosa tõlkimisel vene keelest eesti keelde" (On the Typical Shortcomings and Mistakes of Translations From Russian Into Estonian). In Looming (Creativity). No. 3.

—. 1962. "Üht-teist tõlkimisest ja tõlkijatest" (A Little Something About Translation and Translators). In Keel ja Kirjandus (Language and Literature). No. 7. Pp. 385-392.

Sedakova, О. 2014. "М.Л. Гаспаров и инерция советского перевода. Вольность и точность" (M. L. Gasparov and the Inertia of Soviet Translation. Liberty and Accuracy). In Гаспаровские чтения (Gasparov Readings). Москва (Moscow): Издательство РГГУ. Рp. 99-114.

Sütiste, E. 2009. "Märksõnu eesti tõlkeloost 1906-1940: tõlkediskursust organiseerivad kujundid" (Keywords of the Estonian Translation History of the 1906-1940s: The Images Organize the Discourse of Translation). In Keel ja Kirjandus (Language and Literature). No. 12. Pp. 904-908.

Torop, P. 1999. "Tuglase tõlkeloomingu eripärast" (On the Characteristic Features of the Translation Activities of Tuglas). In Kultuurimärgid (Culture Signs). Tartu: Ilmamaa. Pp. 112-118.

- 2002. "Tõlkesuund" (Translation Direction). In Kohandumise märgid (Adaptation Signs). Koost. ja toim. V. Sarapik, M. Kalda, R. Veidemann (Compiled and edited by V. Sarapik, M. Kalda, and R. Veidemann). Tallinn: Underi ja Tuglase Kirjanduskeskus. Pp. 195-206.

. 2011. Tõlge ja Kultuur (Translation and Culture). Tartu:
Tartu ülikooli kirjastus.

Witt, S. 2011. "Between the Lines: Totalitarianism and Translation in the USSR." Contexts, Subtexts and Pretexts: Literary Translation in Eastern Europe and Russia. Benjamins Translation Library 89(12):149-170.

—. 2016а. "Концепт 'советской школы' перевода-дитя позднего сталинизма" (Concept 'the Soviet School of Translation'-Child of the Late Stalinism). Второй всесоюзный съезд советских писателей (1954). Идеология исторического перехода и трансформация советской литературы. Сборник статей [The Second Congress of the Soviet Writers (1954). Ideology of Historical Transition and Transformation of the Soviet Literature. Collection of Essays]. Санкт-Петербург (St. Petersburg): "Пушкинский Дом".

. 2016b. "Byron's Don Juan in Russian and the 'Soviet School of Translation'." Translation and Interpreting Studies 11(1):23-43. John Benjamins Publishing Company.

\section{Bios}

Ljubov Kisseljova, Ph.D., professor, Chair of Russian Literature, Head of the Department of Slavic Studies, Faculty of Arts and Humanities, University of Tartu, Estonia; research fields: national ideology, Russian literature and culture of the 18th-19th centuries, comparative Russian-Estonian studies.

Lea Pild, Ph.D., associate professor of Russian Literature, Department of Slavic Studies, Faculty of Arts and Humanities, University of Tartu, Estonia; research fields: translation studies, Russian literature of the 19th-20th centuries, comparative Russian-Estonian studies. 